\title{
Formation of quality and safety of offal sausages
}

\author{
Lina Bilyk, Natalia Popova
}

National University of Food Technology, Kyiv, Ukraine

Keywords:

Meat

Raw

By-products

Sausages

Quality

Safety

\section{Article history:}

Received

29.01.2018

Received in revised form 26.05.2018

Accepted

29.06.2018

\section{Corresponding author:}

Natalia Popova

E-mail:

Nata_2506@ukr.net

\section{DOI:}

$10.24263 / 2310-$

1008-2018-6-1-8

\section{Abstract}

Introduction. The research was carried out to determine the influence of the method of packaging sausages on the period of their storage.

Materials and methods. The research was carried out on the samples of offal sausages. These samples are made in production conditions. The $\mathrm{pH}$ of sausages and moisture content were studied. The $\mathrm{pH}$ level was investigated by potentiometric method, dry content was investigated in the sausage moisture content.

Results and discussion. The water content of the product is closely related to the stability of the product during storage and its transportability, as well as the suitability for further processing, as excess moisture promotes the flow of enzymatic and chemical reactions, activates the activity of microorganisms, including those that cause damage to the product, in particular its mold. In this regard, the moisture content in the product determines the terms and conditions for its storage.

The optimum moisture content in off-sausage is $52 \%$.

The moisture content of sausage can be influenced by various factors, such as temperature and storage conditions, the type of packaging chosen for sausage wares, and the terms of its storage.

In the course of the research carried out, this indicator changed as follows:

in the control sample did not go beyond the norm, in fresh sausage, without packaging for 6 days, the storage rate decreased to $44 \%$, in frozen - to 50 . In sausage, which was stored in a plastic bag, the mass fraction of moisture increased to $55 \%$, and in sausage in parchment up to $53 \%$.

$\mathrm{pH}$ is an indicator of the degree of freshness of sausage products. The value of active acidity plays an important role in the storage of sausage products. Changing this indicator in the direction of alkaline environment indicates the beginning of the development of microorganisms and the beginning of damage to sausage.

The optimum $\mathrm{pH}$ value for offal sausage is 6-7.

In the analysis of the samples studied, the following results were obtained:

fresh sausage without packaging (6 days study) -7 , frozen sausages -6.5 , sausages in a plastic bag -7.5 , sausages in parchment-7.2.

Conclusions. The formation of the qualitative and safe product is affected by a number of indicators such as moisture content and $\mathrm{pH}$ of the product. In this case, it is important to choose a quality and efficient packaging. According to the conducted researches, the best packaging method is parchment packing. 


\section{Introduction}

Today, meat and sausage products market is experiencing both negative and positive changes. According to the technical report, among the negative ones can be distinguished such as: depressed state of the meat market; large-scale using of cheap imported raw materials as an alternative to more expensive domestic; increase in energy prices and the main components of the sausage production; constant fluctuation (increase) prices of finished products; reduction of qualitative and taste indicators in pursuit of a mass consumer with low solvency; monopolization of the market - crowding out of the network of small and mediumsized producers; the export of domestic sausage products remains in perspective. The positive changes concern with: renovation of production facilities; the desire of produce in the manufacturing of competitive products from high quality raw materials; the activation of brand products and the expansion of assortment presence in the middle and low-end segments; an increase in the volume of production of fine-packed products, as well as smoked and dried sausages in branded packaging; the introduction of new national standards for meat and meat products that allow the release of new names of sausage products. All these positive/negative trends strongly affect the industry. For producing of high-quality products manufacture should use all possible measures.

One of such measures is to improve the quality of the production sausage products, namely, offal sausages which, due to its high taste, low cost and consumer properties has high demand among the population. The consumption of offal sausages, in the total amount is almost $40 \%$.

The influence of the method of packaging offal sausages for the period of their storage is still not established. The aim of this study was to determine the influence of the method of packaging sausages on the period of their storage.

\section{Materials and methods}

The research was carried out on the samples of offal sausage containing in its composition pigs' buckies, fancy beef, starch and spices. These samples are made in production conditions.

The main physical and chemical parameters that reflect the possible processes of deterioration of the product were selected $\mathrm{pH}$ and moisture content. In this case, research methods such as potentiometric, for determination of $\mathrm{pH}$ and drying method for determination of moisture content were used.

The essence of the potentiometric method is to measure the difference between the electromotive force of two electrodes. One of them is a measuring one, and the other one is auxiliary. In addition, both of these electrodes should be placed in the test solution. Consequently, the method of analysis is based on the measurement of the EMF of the galvanic elements. Under these elements just understand the connection of two electrodes, one of which, as it was spoken earlier, an indicator, and the other is necessary for comparison.

To determine the $\mathrm{pH}$, add $2 \mathrm{~g}$ of the crushed product to the porcelain mortar, add $2.5 \mathrm{~g}$ of fine roasted sand and $6 \mathrm{~g}$ of ethanol. Rubbing the mortar for 4 minutes and filtering through a folded filter. 3-4 drops of filtrate by a glass rod on a prism of a refractometer and record the results.

To determine the mass fraction of moisture, the most accurate results are obtained by drying the product to a constant mass at $100-105^{\circ} \mathrm{C}$ in the drying cabinet. This method refers to arbitration, which determines the correctness of all newly developed methods. 
To accelerate drying, it is recommended to increase the porosity of the product by mixing it with solid material (sand) and reducing the thickness of the drying layer. The weight of the product is weighed, ground and calculated according to the appropriate formula.

The moisture content in the material is characterized by an indicator of the mass fraction of moisture $(\mathrm{W})$ - it is expressed in percentage of the ratio of the weight difference of the product type before and after drying to the weight of the sample prior to drying $W=\left(m_{1}-m_{2} / m_{2}\right) * 100 \%$, where $\mathrm{m}_{1}$ - weight of weight loss before drying, $\mathrm{g} ; \mathrm{m}_{2}$ - weight of weight loss after drying, g.

In an aluminum bake, pour the sand in an amount that is 2-3 times the weight of the product $(3 \mathrm{~g})$, put a glass patch and dry for 30 minutes at a temperature of 150 degrees for the celcius. In the dry sand bake add the weight of the product and mix with a glass rod. Put the resulting mixture in a drying oven for drying. We dry for 1 hour. Cool in a desiccator and weigh. The results are calculated according to the formula.

Currently, consumers prefer to import producers, as there is a misconception about the poor quality of domestic products. The main task of modern meat processing enterprises is gaining popularity on the market by manufacturing high-quality and safe products with minimal losses.

During the processing of cattle (cattle) significant waste of secondary raw materials is created that is not sufficiently fully and rationally used for food purposes. It is known that about $1 / 3$ of the total amount of raw materials of the meat industry is byproducts, blood, bones and others. These all products contain a significant amount of animal protein. Industrial processing of by-products, in comparison with their implementation not in the processed form, allows you to increase profits in general more than 10 times. Consequently, the use of offal raw materials is one of the possible ways of setting up rational production.

However, despite the obvious economic effect, the processing of by-products for food purposes constrains the idea of their low nutritional and biological values, the complexity and low efficiency of methods and techniques for their food processing and processing.

Offal sausages include edible secondary slaughter products. By their nutritional value they are divided - on by-products I and II categories. To category 1 include byproducts that are equated with meat - tongue, liver, kidneys, brains, heart, udder, diaphragm, meat-eating tail, meat oblique. Category II includes less valuable offspring - pork scab, stomach, calico, sichug, lungs, beef heads without tongue to the brain, trachea, spleen, swine legs and ears, pylon joint, lips, beef ears, meat-and-bone pig's tail. Offal sausages contain an average protein of $9-17$, fat $-1,2-16 \%$. The energy value of their $410-1402 \mathrm{~kJ}$.

According to studies of the chemical composition of by-products, they contain significant resources of animal protein: in the spleen, lungs, scars, squish, calcium, esophagus $-15-19 \%$, ears and lips $-21-25 \%$. Of which valuable protein - in the spleen $-13,2 \%$, in the lungs and esophagus $-10 \%$ [3]. By-products have a positive effect on juicing and the motor function of the stomach and intestines, and, moreover, collagen is a source of natural fibers that are healthy for health.

Specific for collagen properties are increased water and fat retaining ability, gelforming ability to expand the scope of application of collagen-containing by-products [5].

They can be used as a filler for raw materials when cooked sausages (cooked and semismoked), meat loaves and chopped semifinished products. The highest amount of collagen is found in the scar, lips and ears - respectively $50 \%, 66 \%$ and $71 \%$ of collagen to the total protein. 


\section{Results and discussion}

The quality and safety of offal sausages form organoleptic, physico-chemical, microbiological parameters, form the maximum permissible levels of the content of toxic elements, and the content of radionuclides.

\section{Requirements for organoleptic parameters of offal sausages}

According to organoleptic parameters, sausages must meet the following standards:

The surface of the loaves - clean, dry, without spots, glabrations, shell damage and stuffed stuffing, the consistence is elastic, the appearance of minced meat on the cut - the minced meat is uniformly mixed, from pink to dark red, without gray spots and cavities and contains pieces of fat, pork, breasts, beef or lamb fat, tanks (sacks), etc. It is allowed to reject the size of individual pieces at the cut of their diagonal.

Taste and smell - taste pleasant, slightly sharp, salty, with a pronounced aroma of spices and smoked, with the smell of garlic or without it, without foreign taste and smell.

The shape and size of the loaves - the loaves are straight or slightly curved in length from $15 \mathrm{~cm}$ to $50 \mathrm{~cm}$, in the belly - scratched bars in length from $15 \mathrm{~cm}$ to $35 \mathrm{~cm}$

Physico-chemical parameters must meet the requirements given in Table 1.

Table 1

Physico-chemical parameters of sub-product sausage

\begin{tabular}{|l|l|c|}
\hline № & \multicolumn{1}{|c|}{ Name of indicator } & $\begin{array}{c}\text { Characteristic and } \\
\text { norm }\end{array}$ \\
\hline 1. & Mass fraction of moisture, \% & 55 \\
\hline 2. & Mass fraction of protein, \% & 13 \\
\hline 3. & Mass fraction of fat & 45 \\
\hline 4. & Mass fraction of kitchen salt, \% & 4,5 \\
\hline 5. & Mass fraction of sodium nitrite, \% & 0,005 \\
\hline 6. & Mass fraction of starch, \% & 4,5 \\
\hline 7. & $\begin{array}{l}\text { Temperature in the breadth of the loop, during release } \\
\text { in the implementation }\end{array}$ & from 0 to 12 \\
\hline
\end{tabular}

Microbiological indicators are given in Table 2.

Table 2

Microbiological indicators of offal sausages

\begin{tabular}{|l|c|}
\hline \multicolumn{1}{|c|}{ Microbiological indicators } & Norma \\
\hline $\begin{array}{l}\text { Bacteria of the group of intestinal sticks } \\
\text { (BGKP), in } 1.0 \mathrm{~g} \text { of the product }\end{array}$ & not allowed \\
\hline $\begin{array}{l}\text { Sulfonating cholestridia: }-0.01 \mathrm{~g} \text { of the } \\
\text { product }\end{array}$ & not allowed \\
\hline Staphilococus aureus in $1,0 \mathrm{~g}$ of the product & not allowed \\
\hline $\begin{array}{l}\text { Pathogenic microorganisms, in particular } \\
\text { bacteria of the genus Salmonella, in } 25 \mathrm{~g} \text { of } \\
\text { the product. }\end{array}$ & not allowed \\
\hline L.Monocytogenes, in $25 \mathrm{~g}$ of the product. & not allowed \\
\hline
\end{tabular}


The maximum permissible levels of the content of toxic elements of offal sausage must not exceed the standards specified in Table 3.

Table 3

Maximum permissible levels of the content of toxic elements

\begin{tabular}{|c|c|}
\hline Name of toxic element & Maximum permissible levels \\
\hline Lead & 0.50 \\
\hline Cadmium & 0,05 \\
\hline Mercury & 0,03 \\
\hline Copper & 5,00 \\
\hline Zinc & 70,00 \\
\hline Arsenic & 0,10 \\
\hline
\end{tabular}

The content of radionuclides in sausages should not exceed the permissible levels set by the PL: ${ }^{137} \mathrm{Cs}-200 \mathrm{~Bq} / \mathrm{kg} ;{ }^{90} \mathrm{Sr} \mathrm{r}-20 \mathrm{~Bq} / \mathrm{kg}$.

Also, the quality and safety of the product is influenced by the way of its packaging.

The study of the terms of storage of offal sausage, depending on the method of packaging, was conducted.

The most popular types of packaging are vacuum packaging or packaging in the MGS environment [9]. Modified gas medium (MGS) is a mixture of gases that are present in the usual atmosphere, but the content of one or two gases that slow down the process of food spoilage increases with respect to the usual air cushion. Nitrogen serves as a filler to reduce the concentration of other gases inside the package, as well as prevents the packaging from swirling with the dissolution of carbon dioxide in the product. Oxygen slows the growth of anaerobic pathogenic fungi, but in many cases, it does not directly affect the increase in shelf life. So, as a result of scientific studies, it was found that for storage of the properties of meat for 6 days, you can use a mixture of MGS with 20\%

carbon dioxide and $80 \%$ oxygen. Carbon dioxide prevents the reproduction of pathogenic bacteria and fungi, and oxygen allows you to save the fresh red color of the meat, prevents the transition of muscular red dye in brown methymoglobin.

The object of the study was semi-smoked sausage.

The control sample was selected sausage of second-class offal, which was produced by PJSC "Kozyatynsky meat-packing plant", and differs from other sausage products by the fact that it includes such by-products as tanks of pork and headed beef.

Store data for sausage products, usually at a temperature not higher than $6{ }^{\circ} \mathrm{C}$ and 75 $80 \%$ relative humidity. The term of sales of sausages is 6 days.

When storing the product in refrigerating chambers, at a temperature of $-14{ }^{\circ} \mathrm{C}$, it is stored much longer, but the appearance, the value of such a product will already be broken.

Sausage shell and packaging directly affect how much it can be stored. Material for the production of sausage can be both natural and artificial raw materials.

Natural materials can serve as intestines of different animals - lamb, pork, beef, etc. Artificial membranes are mainly made from various plastics, viscose, cellulose, and sometimes tissue. It is these shells most often used in production, since boiled sausage in them has a much longer shelf life.

The most common of artificial coatings is a shell of polyamides components that have high strength and reliability. In addition, they have antibacterial properties and do not allow to enter the microbes and bacteria, resistant to the radiation of UV-protecting light 
product from premature spoilage, and their low ability to pass gaseous substances do not allow foreign smells to spoil the aroma of sausage and prevents penetration of excess moisture.

Sausage cooked in a similar shell can store freshness for about 2 weeks, but once its integrity is broken, the product will need to be taken in the next few days.

The research was conducted for 6 days, the control points of the tests were 2,4 and 6 days. The samples under investigation were 4, that is, a sample of sausage sub-product without packaging, in polyethylene packaging, in parchment and a sample stored in a freezing chamber at a temperature of $-7^{\circ} \mathrm{C}$.

During the study, the quality of sausage during the storage of sausage was determined by the content of the mass fraction of moisture and the level of $\mathrm{pH}$, which is not standardized in this type of sausages, but is an indicator that indicates the degree of freshness of sausage products. The value of active acidity plays an important role in the storage of sausage products. Changing this indicator in the direction of alkaline environment indicates the beginning of the development of microorganisms and the beginning of damage to sausage.

During storage, the organoleptic parameters of offal sausages also changed (results of the state of sausages stored in parchment, polyethylene and without packaging for 6 days storage):

Baton surface - wet, sticky, consistency - elastic,

taste and smell - there is an extraneous flavor and smell.

The sausage wares stored in the freezer chamber changed their color from reddish to light brown.

Changing the moisture content during storage is a natural process. This is due to mass exchange, with the important role played by the degree of binding of moisture in the product [4].

\section{Mass fraction of moisture of the offal sausage}

The results of the research are presented in Table 4.

Results of the study of the mass fraction of moisture of the offal sausage

Table 4

\begin{tabular}{|c|c|c|c|c|}
\hline \multirow{2}{*}{ Experimental sample } & \multicolumn{4}{|c|}{ Mass fraction of moisture, \% } \\
\cline { 2 - 5 } & \multicolumn{4}{|c|}{ Duration of storage } \\
\cline { 4 - 5 } & Control sample & 2 days & 4 days & 6 days \\
\hline \multirow{2}{*}{5} & 51 & 46 & 44 \\
\hline \multirow{2}{*}{5} & & 52 & 52 & 51 \\
\hline \multirow{nnnyy}{*}{5} & & 52 & 53 & 55 \\
\hline Fresh sausage, without packaging & & 52 & 52 & 54 \\
\hline Sausage in a plastic bag & & & &
\end{tabular}

After analyzing the data obtained, we can conclude that the mass fraction of moisture of fresh sausage, without packaging decreased, as the product without packaging is characterized by drying out. The bulk of the moisture content of frozen sausages decreased, the polyethylene increased significantly and increased slightly in parchment, as this type of packaging was able to accumulate moisture. 


\section{Active acidity of the offal sausage}

According to the results of the study of active acidity, it was found that frozen sausage does not change the active acidity, so the processes of damage do not occur, fresh sausage, which was stored without increasing the $\mathrm{pH}$. In sausage, which is stored in polyethylene and parchment, the index of acidity also increases significantly significantly, hence the possible processes of damage.

The results of active acidity studies are presented in Table 5.

Table 5

Results of study of active acidity of sausage subproduct

\begin{tabular}{|c|c|c|c|c|}
\hline \multirow[t]{3}{*}{ Experimental sample } & \multicolumn{4}{|c|}{ Active acidity } \\
\hline & \multicolumn{4}{|c|}{ Duration of storage } \\
\hline & Control sample & 2 days & 4 days & 6 days \\
\hline Fresh sausage, without packaging & \multirow[b]{4}{*}{$6-7$} & 6,5 & 6,8 & 7 \\
\hline Frozen sausage & & 6,5 & 6,5 & 6,5 \\
\hline Sausage in a plastic bag & & 6,8 & 7,0 & 7,5 \\
\hline Sausage in parchment & & 6,78 & 6,90 & 7,2 \\
\hline
\end{tabular}

Consequently, 4 samples of offal sausage, namely sausage without packaging, frozen, in polyethylene packaging and in parchment, were investigated. As a result of researches it was discovered that the maximum shelf life of off-product cooked sausages is 6 days, at a temperature from 0 to $+6{ }^{\circ} \mathrm{C}$. When frozen sausages, quality indicators remain stable, therefore freezing is effective for extending the storage period of sausages, but at the same time the food value of the product is lost.

The use of polyethylene for packaging is possible, but in this case the product does not behave as stable: moisture content increases significantly, thus accelerating the process of deterioration. So the use of this kind of packaging is not effective. Packing in parchment is the best way to pack.

\section{Conclusions}

Production of meat and meat products is an important component of the food industry, and its development depends on solving a number of problems: provision of domestic livestock feed to the feed base; optimization of the assortment of production of meat processing products of the domestic producer in accordance with the needs of the market, as well as the formation of a quality and safe product. In this case, it is extremely important to select a quality and efficient packaging of the product. According to the research, the best option is packaging of the product in parchment, because when using such packaging, the quality parameters of the product, such as moisture content and $\mathrm{pH}$ are stable. 


\section{References}

1. Kundileeva G. (2012), Esential problems of development of meat sector in agriculture in Ukraine International Conference on European Science and Technology, Munich, p3. 482-485.

2. Kholod A. The problems and prospects of meat production in Ukraine, NUFT, Kyiv.

3. Pavelko V., Hrybkov S., Zaslsvsky A., Dmytrenko D. (2016), Mathematical modeling of thermal processing of meat products, Food and Environment Safety, 15(4), pp. 329333.

4. Essien E. (2003), Sausage manufacture. Principles and practice, Woodhead Publishing \& Boca Raton, CRC Press.

5. Feiner G. (2006), Meat products handbook. Practical science and technology, CRC Press.

6. Yi-Chen Lee, Yi-Fen Chen, Ya-Ling Huang, Hsien-Feng Kung, Yung-Hsiang Tsai (2016), Hygienic quality, adulteration of pork and histamine production by Raoultella ornithinolytica in milkfish dumpling, Journal of Food and Drug Analysis, 24 (4), pp. 762-770.

7. Warriss P.D. (2000), Meat science, An introductory text, CABI Publishing.

8. Kuzmin O., Suikov S., Niemirich O., Ditrich I., Sylka I. (2017), Effects of the water desalting by reverse osmosis on the process of formation of water-alcohol mixtures. ${ }^{1} \mathrm{H}$ NMR spectroscopy studies, Ukrainian Food Journal, 6(2), pp. 239-257.

9. Snezhko A.G., Fedotova A.V. (2008), The use of nanotechnology for the packaging of meat products, Meat Industry, 2, pp. 22-24.

10. Kenneth W. McMillin (2017), Advancements in meat packaging, Meat Science, 132, pp. 153-162.

11. Steven M. Lonergan, David G. Topel, Dennis N. Marple (2019), Chapter 15: Packaging for meat and meat products, The Science of Animal Growth and Meat Technology (Second Edition), pp. 255-269

12. Telychkun V.I., Gavva O.M., Telychkun Yu.S., Gubenia O.O., Desyk M.H., Chepeliuk O.M. (2017), Tekhnolohichni kompleksy kharchovykh vyrobnytstv, Stal, Kyiv.

13. Litovchenko I., Taran V., Beseda S., Hadjiiski W. M., Stefanov S.V. (2011), Computer modelling of movement of meat raw material on pipelines, The 7th International Conference «Integrated systems for agri-food production», Nyiregyhaza, Hungary, pp. 211-214.

14. Fellows P. (2013), Food processing technology. Principles and Practice. Second Edition, CRC Press.

15. Brennan J. G., Alistair S.G. (2011), Food Processing Handbook, 2nd Edition, Wiley$\mathrm{VCH}$ Verlag $\mathrm{GmbH} \& \mathrm{Co}$.

16. Holah J., Lelieveld H.L.M. (2011), Hygienic Design of Food Factories, Elsevier

17. Kennedy S. (2017), Food Protection and Security. Preventing and Mitigating Contamination during Food Processing and Production, Woodhead Publishing.

18. Lelieveld H., Holah J., Gabrić D. (2016), Handbook of Hygiene Control in the Food Industry (Second Edition), Elsevier. 